\title{
Managing Diplodia Tip Blight of Landscape Austrian Pines
}

\author{
John R. Hartman, Lisa J. Vaillancourt, Jennifer L. Flowers, and Amy M. Bateman
}

\begin{abstract}
A long-term survey of 449 Austrian pines growing on the University of Kentucky campus revealed that Diplodia tip blight disease killed $84 \%$ of the trees during a 15-year period and that the pines developed increasing levels of disease as they aged. Treatments consisting of the fungicides oxycarboxin, debacarb, or tebuconazole or water were injected into the lower trunk and root flare of individual trees in a block of mature, diseased pines for 4 years. The fungicide treatments did not significantly affect disease levels. The causal fungus could be isolated readily from diseased and symptomless shoots regardless of the treatment. Diplodia pinea was very sensitive to tebuconazole and debacarb in in vitro fungicide tests. Basal drenches with paclobutrazol affected shoot growth but did not significantly reduce tip blight disease levels or tree mortality. Under midsouth United States climate conditions, Diplodia tip blight of Austrian pines is destructive and very difficult to manage.

Key Words. Diplodia pinea; fungicide basal drench; fungicide injection; Pinus nigra; Sphaeropsis sapinea; Sphaeropsis tip blight.
\end{abstract}

Austrian pine (Pinus nigra) is widely planted in landscapes throughout the central and eastern United States. Introduced from Europe almost 250 years ago, the tree is valued for its ability to withstand urban growing conditions while providing a pleasing dark green appearance whether used as a specimen plant or as part of a landscape screen. Austrian pines typically grow to a height

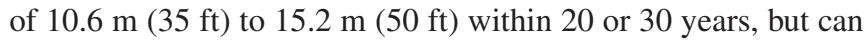
attain twice that height during their lifetime (Dirr 1998). Of the 3,000 to 4,000 trees growing on the University of Kentucky campus in recent decades, at least $10 \%$ have been Austrian pines.

Diplodia tip blight, also known as pine tip blight or Sphaeropsis tip blight, is a serious disease of conifers worldwide. The fungal pathogen, Diplodia pinea (syn. Sphaeropsis sapinea), causes Diplodia tip or shoot blight (previously known as Sphaeropsis tip blight), which is especially devastating to two-needled pines such as Austrian pine (Sinclair and Lyon 2005). Exotic pines such as Austrian, Mugo, and Scots pines were found to be more susceptible to tip blight than United States native pines (Waterman 1943). Diplodia tip blight disease of Austrian pine is enhanced under stressful growing conditions found in urban landscapes such as drought (Bachi and Peterson 1985).

A preliminary survey of more than 400 Austrian pines on the University of Kentucky campus showed that Diplodia tip blight disease progressively worsened as Austrian pines in the landscape aged (Hartman et al. 1995). Further analysis revealed that almost $40 \%$ of symptomless Austrian pine shoots harbored latent D. pinea infections (Flowers et al. 2001), which were probably kept in check by tree defenses (Flowers et al. 2006). Latent infections may convert to pathogenic ones when trees are stressed. $D$. pinea was recovered from symptomless needles, stems, buds, immature cones, and male flowers. In symptomless stems, the fungus was recovered more frequently from bark and phloem tissues than from the xylem and pith. A polymerase chain reaction (PCR) test was developed to detect $D$. pinea in pine tissues (Flowers et al. 2003) to eliminate the requirement for destructive sampling needed to grow the pathogen in culture.

Success in management of Diplodia tip blight with chemical applications of fungicides to the foliage has been inconsistent.
Disease was reduced significantly with Bordeaux mixture applied early in the growing season (Peterson 1977). In that study, trees were found to be most susceptible during the early part of shoot (candle) elongation before needles began to elongate. Based on these findings, a standard recommendation suggesting three springtime applications of fungicide, the first at bud swell, the second as the candles are elongating but just before needle emergence, and the third as needles are emerging from the needle sheaths, was developed. This protocol is generally indicated on the labels for fungicides containing thiophanate methyl such as Topsin-M 70 WP (Cerexagri-Nisso, King of Prussia, PA) or 3336 WP (Cleary Chemical Co., Dayton, NJ). A fungicide application schedule consisting of only two early spring sprays has also been advocated (Tisserat 1993). However, grounds managers reported that a protocol involving foliar application of fungicides was not working on the University of Kentucky (UK) campus and elsewhere (Hartman et al. 1995), possibly as a result of inadequate spray coverage for large trees or imprecise timing resulting from needing to spray large numbers of individual trees over a large landscape during a narrow application window. Furthermore, on institutional landscapes such as the UK campus, application of foliar fungicides is complicated by concerns about human and environmental exposure.

To minimize these chemical exposure concerns, systemic fungicides can be delivered throughout trees by injecting the chemicals directly into small, shallow holes in the outer xylem of the root flare. This provides uniform chemical distribution while minimizing wounding effects and promotes wound closure after injection (Stipes 1988). Fungicide injections have been used for management of canker diseases (Helton and French 1962; Helton and Harvey 1963; Elliott and Edmonds 2008). Oxycarboxin, a phenylamide (Carboject, no longer available), debacarb, a benzimdazole (Fungisol), and tebuconazole, a sterol biosynthesis inhibitor (Tebuject) (Mauget, Inc.) are examples of fungicides that can be injected into trees.

Paclobutrazol is a plant growth regulator chemical that inhibits synthesis of the plant hormone gibberellin. For the arboricultural industry, paclobutrazol is sold under the trade name Cambistat 
(Rainbow TreeCare Scientific Advancements, Minnetonka, MN). Some effects of paclobutrazol are reduction in shoot growth and stimulation of root development. The triazole-based chemical also has fungicidal activity (Jacobs and Berg 2000; Blaedow et al. 2006). Preliminary evidence suggests that application of paclobutrazol may improve tree health and reduce the effects of plant disease (Anonymous 2002). Paclobutrazol is applied as a soil drench around the base of the tree and is taken up into the tree systemically. Paclobutrazol may not have any effect until the year after the treatments, but its benefits are thought to last for 3 years.

One objective of this research was to document the decline of a population of Austrian pines over a 15-year period resulting from Diplodia tip blight. Another objective was to test other chemical approaches as an alternative to spraying the foliage with fungicides for reduction of disease levels and/or latent infections.

\section{MATERIALS AND METHODS}

\section{Austrian Pine Tip Blight Survey}

Austrian pines growing in landscape groupings on the UK campus $\left(38.0^{\circ}\right.$ north, $84.5^{\circ}$ west), located in Lexington, Kentucky, U.S., were surveyed for tip blight disease during the month of July eight times over 15 years from 1992 to 2007. The first year, each tree was identified according to location and position near campus buildings so that subsequent surveys could be correlated. For each tree, the age was estimated by counting the number of whorls of branches along the main trunk, and an estimate of whole-tree percent tip blight (number of dead shoots versus number of total [dead plus live] shoots) was made. In cases where lower branches had been removed as a result of tip blight, age and disease estimates were adjusted accordingly. The presence of $D$. pinea-infected cones, insect infestations, and abiotic disorders was also recorded.

\section{Fungicide Injection for Tip Blight Management}

Two distinct groups of UK campus Austrian pines were selected for injection treatments. The first experiment was done in a mature (20 to 22 years old) stand of diseased (1\% to $50 \%$ tip blight) pines and the second experiment was done in a maturing (13 to 14 years old) disease-free stand. Disease symptoms were evaluated in mid- to late summer each year by estimating the percent of diseased shoot tips per tree. Diseased branches previously removed for sanitation purposes were included in the estimate.

\section{Expt. 1.}

Sixteen pines located on traffic islands on the UK campus received one of four treatments. Trees were assigned to groups so that each treatment was applied to trees with a similar range of symptoms. Treatments, arranged in a randomized complete block design and replicated on four individual trees, consisted of injections of 1) oxycarboxin; 2) debacarb; 3 ) tebuconazole; and 4) water used as a control. Fungicides were used at labeled rates, approximately $14 \mathrm{mg}$ active ingredient per inch tree diameter at breast height. Injections into basal root flares were started when the pine shoot candles were partly elongated on 8 May 1999, 6-9 May 2000, 5 May 2001, and 29-30 May 2002; capsules were removed 4 to 12 days after injection. As a result of the demise and removal of several of the traffic island trees in the first year, eight additional 20-year-old trees located around the perimeter of a UK campus parking lot nearby were injected in May 2000, 2001, and 2002. Trees were grouped into randomized complete blocks, and each treatment was replicated five or six times with each replicate being an individual tree.

\section{Expt. 2.}

Forty pines comprising a screen planting on the UK campus were injected in 1999, 2000, 2001, and 2002 as described in Expt. 1. The experiment was designed as a randomized complete block experiment with ten replicates.

\section{Recovery of $D$. pinea from Shoots of Treated Trees}

In July of 2000, 2001, and 2002, shoot, bud, and needle samples (two each) from asymptomatic and diseased shoots were collected from each treated tree, and the pathogen was cultured on acidified potato dextrose agar (APDA) using standard microbiologic techniques. The fungal cultures were identified and confirmed microscopically after inoculation of autoclaved pine needles using the method described in Flowers et al. (2001).

\section{In Vitro Test of Injected Fungicides}

Oxycarboxin, debacarb, and tebuconazole were each tested in the laboratory for fungicidal activity against $D$. pinea and compared with water controls. Fungicides were incorporated into APDA in Petri plates at the following rates: 1, 2, 3, 4, 5, 6, and $1000 \mathrm{ppm}$. Plugs (4 mm [0.16 in] diameter) of mycelium from actively growing cultures of $D$. pinea were transferred to the plates. Radial growth from the original plug was measured after 4 days. The test was replicated four times, and the lowest fungicide concentrations that prevented fungal growth in the experiment were calculated as effective doses.

\section{Paclobutrazol Basal Drench for Tip Blight Management}

Suspensions of paclobutrazol were applied at label rates $(3.7 \mathrm{~g}$ [a.i.]/2.5 cm diameter at breast height) to the bases of 20 mature (17 to 19 years old) Austrian pines growing in a screen planting on the UK campus in July 2003. A shallow encircling trench was carved into the soil adjacent to the trunk and buttress roots of each tree and the paclobutrazol suspension was distributed uniformly into the trench. After the suspension had soaked in, trenches were covered with soil. The experiment, established in a randomized complete block arrangement, was replicated five times with each replicate consisting of four trees per treatment. The pines selected for this experiment had varying levels of tip blight disease ranging from $1 \%$ to $30 \%$ dead tips, and each block of trees contained trees with a similar range of symptoms. An equivalent number of experimental controls were treated with water.

Pines were evaluated in July of 2004, 2005, and 2006 for levels of tip blight disease, detection of latent infections using PCR assays (Flowers et al. 2003), tree survival, and treatment effects on tree shoot length and trunk diameter.

\section{RESULTS}

\section{Austrian Pine Tip Blight Survey}

In 1992, the survey identified 486 Austrian pines on the UK campus, with an average age of 15.1 years, distributed among 47 landscape groupings. Of these, 37 trees were lost to construction in subsequent years, leaving 449 trees to be monitored for the entire 15-year period. From the original 449 trees, 377 (84\%) 
died or were removed as a result of excessive tip blight disease until only 72 remained in 2007. Mature pine cones with $D$. pinea pycnidia embedded in the cone scales were usually observed on trees that were 13 years old or older. Tip blight symptoms in the lower branches typically occurred in subsequent years. Pine tip blight incidence increased as trees aged (Figure 1).

\section{Fungicide Injection for Tip Blight Management}

\section{Expt. 1.}

After 3 years of fungicide injections, trees in Expt. 1 continued to die until 2002, when no new trees died. Tip blight disease in these mature trees in 2002 increased $121 \%$ to $245 \%$ over levels in 1999 (Figure 2). The increase in disease was slowest in debacarb-treated trees, in which 2002 disease levels were $121 \%$ of 1999 disease levels. Disease severities for other treatments in 2002 were approximately double the levels seen in 1999.

\section{Expt. 2.}

For Expt. 2 using the younger, less diseased trees, tip blight levels gradually increased (Figure 3). In 1999, there was no noticeable disease in this plot; by 2002, disease ratings ranged from $13 \%$ to $23 \%$ but showed no noticeable treatment effect.

\section{Isolation of $D$. pinea from Shoots of Treated Trees}

In Expt. 1, S. sapinea was isolated from most of the diseased and symptomless shoots from 2000 to 2002 and there were no significant differences between treatments (Table 1). In Expt. 2 , the pathogen was isolated significantly more frequently from diseased shoots than from asymptomatic shoots from the same trees (Table 1). Sphaeropsis sapinea recovery increased over the 3 -year period reflecting the increase in disease over the same time period. Diseased shoots in Expt. 2 showed significant differences in the frequency of $S$. sapinea isolations between tebuconazole and oxycarboxin treatments in 2000. Significant treatment differences were not observed in 2001 and 2002.

\section{In Vitro Test of Injected Fungicides}

The effective dose for complete inhibition of $D$. pinea hyphal growth on PDA amended with fungicides can be determined from the data presented in Table 2. Based on this test, tebuconazole completely inhibited fungal growth at a rate of only $1 \mathrm{ppm}$. The effective dose may be even lower, but this concentration

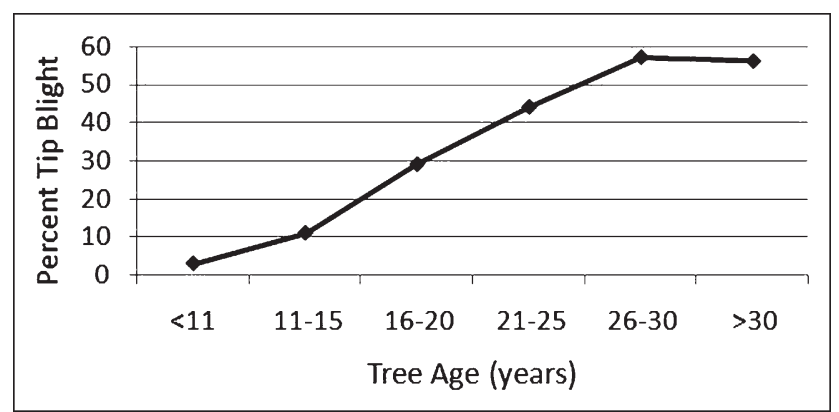

Figure 1. Relationship between tree age and average percent tip blight for all trees surveyed for all observation years. Number of trees evaluated per age category over all 8 years of observation ranged from 26 (greater than 30 ) to 1043 (16 to 20).

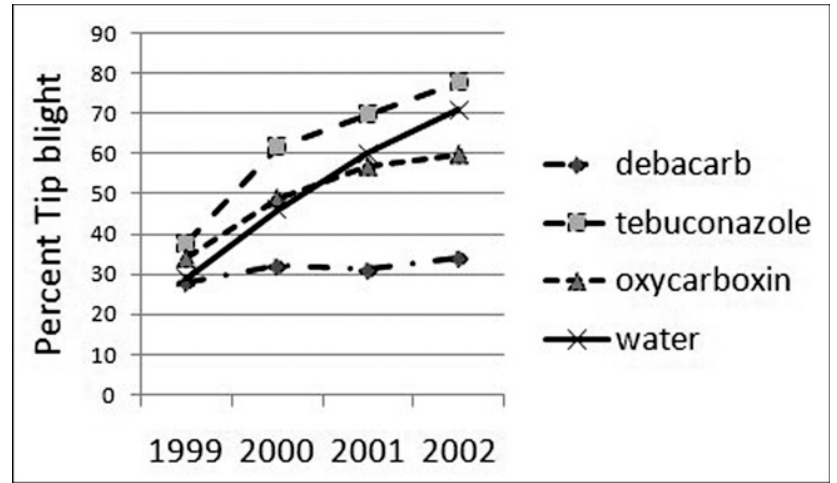

Figure 2. Effect of fungicide injections on percent blighted shoot tips, 1999 to 2002, for mature diseased University of Kentucky campus Austrian pines (four to six replicates). Treatment means are not statistically different within any sampling year (Waller-Duncan K-ratio t-test, $P=0.05$ ).

was the lowest used. The effective dose of debacarb needed to stop fungal growth occurred at $6 \mathrm{ppm}$, which is still good for most fungicidal applications. However, for oxycarboxin, inhibition did not occur until fungicide concentrations reached $1000 \mathrm{ppm}$.

\section{Basal Drench for Tip Blight Management}

Most of the pines in the test groups continued to deteriorate after treatments in 2003, whether treated with paclobutrazol or not, and by 2006, several had to be removed. Average tip blight levels in the remaining trees (2005) were high and were not significantly different between paclobutrazol and water-treated trees. Using PCR, the causal fungus was very commonly detected in symptomless tissues for both treatments. The levels of latent infections varied greatly from tree to tree within each treatment. By the end of the experiment, nearly half of all the trees in the experiment had died from tip blight or had been removed as a result of excessive disease (Table 3 ).

Paclobutrazol-treated Austrian pines grew more slowly than water-treated pines, which is an expected effect of this growth regulator chemical (Table 4 ).

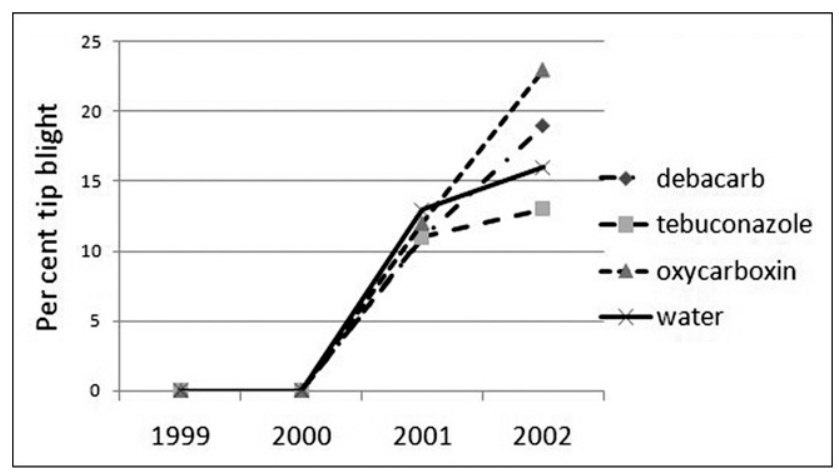

Figure 3. Average percent blighted shoot tips for maturing, less-diseased Austrian pines in Expt. 2 (ten replicates). Treatment means were not significantly different, WallerDuncan K-ratio t-test $(P=0.05)$. 
Table 1. Isolation of Diplodia pinea from University of Kentucky campus Austrian pines. ${ }^{2}$

\begin{tabular}{|c|c|c|c|c|c|c|}
\hline \multirow[b]{3}{*}{ Treatment } & \multirow{2}{*}{\multicolumn{3}{|c|}{$\begin{array}{c}\text { Expt. } 1 \\
\text { Percent recovery of } \\
\text { D. pinea }\end{array}$}} & \multicolumn{3}{|c|}{ Expt. 2} \\
\hline & & & & \multicolumn{3}{|c|}{$\begin{array}{c}\text { Percent recovery of } \\
\text { D. pinea }\end{array}$} \\
\hline & $2000^{y}$ & 2001 & 2002 & 2000 & 2001 & 2002 \\
\hline \multicolumn{7}{|c|}{ Symptomless shoots with $D$. pinea } \\
\hline Debacarb & $55 \mathrm{a}$ & $50 \mathrm{a}$ & $70 \mathrm{a}$ & $8 \mathrm{a}$ & $17 \mathrm{a}$ & $32 \mathrm{a}$ \\
\hline Tebuconazole & $40 \mathrm{a}$ & $50 \mathrm{a}$ & $88 \mathrm{a}$ & $18 \mathrm{a}$ & $30 \mathrm{a}$ & $20 \mathrm{a}$ \\
\hline Water & $67 \mathrm{a}$ & $60 \mathrm{a}$ & $80 \mathrm{a}$ & $23 \mathrm{a}$ & $25 \mathrm{a}$ & $45 \mathrm{ab}$ \\
\hline Oxycarboxin & $46 \mathrm{a}$ & $100 \mathrm{a}$ & $75 \mathrm{a}$ & $25 \mathrm{a}$ & $26 \mathrm{a}$ & $55 \mathrm{ab}$ \\
\hline \multicolumn{7}{|c|}{ Diseased shoots with $D$. pinea } \\
\hline Tebuconazole & $75 a$ & $100 \mathrm{a}$ & $100 \mathrm{a}$ & $69 \mathrm{~b}$ & $87 \mathrm{~b}$ & $90 \mathrm{bc}$ \\
\hline Water & $79 \mathrm{a}$ & $100 \mathrm{a}$ & $100 \mathrm{a}$ & $75 \mathrm{bc}$ & $94 \mathrm{~b}$ & $100 \mathrm{c}$ \\
\hline Debacarb & $80 \mathrm{a}$ & $100 \mathrm{a}$ & $100 \mathrm{a}$ & $79 \mathrm{bc}$ & $100 \mathrm{~b}$ & $100 \mathrm{c}$ \\
\hline Oxycarboxin & $67 \mathrm{a}$ & $100 \mathrm{a}$ & $100 \mathrm{a}$ & $88 \mathrm{c}$ & $93 \mathrm{~b}$ & $100 \mathrm{c}$ \\
\hline
\end{tabular}

${ }^{2}$ Expt. 1, mature severely diseased Austrian pines (four to six replicates). Expt. 2, maturing Austrian pines with lower levels of disease (ten replicates). Both treated with fungicides by trunk injections. Percent shoots yielding D. pinea in culture (ten samples per tree).

${ }^{y}$ Means in a column followed by the same letter are not significantly different; Waller-Duncan K-ratio t-test $(\mathrm{K}=100, P=0.05)$.

\section{DISCUSSION}

\section{Austrian Pine Tip Blight Survey}

In one study of nine "old" and four "young" open-grown Austrian pines in Illinois, the age of the "old" trees averaged 73 years and the "young" trees averaged 27 years (Minckler 1955). Based on our survey, the Austrian pines on the UK campus do not last nearly as long as this, rarely living more than 30 years. In Florida, Diplodia tip blight is reported to disfigure Austrian pines at approximately 25 to 30 years of age (Gilman and Watson 2006) and in Kansas, at approximately age 30 years (Tisserat 1993). This is more in line with our observations; during the 15 years of the UK campus survey, Austrian pines were so disfigured or killed by Diplodia tip blight that they generally needed removal by approximately age 25 to 30 years. During the 15-year interval, frequent summer dry periods and drought (1994, 1999, 2002, 2005, and 2007) could have contributed to increased disease susceptibility of landscape Austrian pines. Pine wilt disease caused by the pine wood nematode, Bursaphalenchus xylophylis, was found in one dying tree but was not considered a major cause of Austrian pine death in this survey.

\section{Fungicide Injection for Tip Blight Management}

The in vitro test of the fungicides used for injection against Diplodia pinea suggest that two of the fungicides, debacarb and

Table 2. Effect of different concentrations (in parts per million) of fungicides on in vitro growth of $D$. pinea (in millimeters) after 4 days growth on acidified potato dextrose agar amended with fungicide.

\begin{tabular}{lrrrrrrrr}
\hline $\begin{array}{l}\text { Fungicide and } \\
\text { concentration }\end{array}$ & $1 \mathrm{ppm}$ & $2 \mathrm{ppm}$ & $3 \mathrm{ppm}$ & $4 \mathrm{ppm}$ & $5 \mathrm{ppm}$ & $6 \mathrm{ppm}$ & $1000 \mathrm{ppm}$ \\
\hline Tebuconazole & 0 & 0 & 0 & 0 & 0 & 0 & 0 \\
Debacarb & 66 & 64 & 38 & 23 & 8 & 0 & 0 \\
Oxycarboxin & 68 & 66 & 63 & 67 & 68 & 65 & 0 \\
Water & 64 & 63 & 69 & 65 & 64 & 67 & 65 \\
\hline
\end{tabular}

Table 3. Effect of paclobutrazol application in 2003 on subsequent Austrian pine tip blight disease incidence, presence of latent Diplodia pinea infections, and tree survival in a landscape screen planting.

\begin{tabular}{lllll}
\hline & \multicolumn{2}{c}{2005 results } & & \multicolumn{2}{c}{2006 results } \\
\cline { 2 - 2 } \cline { 5 - 5 } & $\begin{array}{l}\text { Percent } \\
\text { tip }\end{array}$ & & $\begin{array}{l}\text { Percent shoot tips } \\
\text { with latent } D \text {. pinea }\end{array}$ & $\begin{array}{l}\text { Percent survival } \\
\text { of pines }\end{array}$ \\
Treatment & blight $^{2}$ & & infections & $65 \mathrm{a}$ \\
Paclobutrazol & $22.1 \mathrm{a}$ & & $96 \mathrm{a}$ & $45 \mathrm{a}$ \\
\hline
\end{tabular}

${ }^{2}$ In a column, means bearing the same letter are not significantly different (Waller-Duncan K-ratio test, $P=0.05$ ).

tebuconazole, might have sufficient activity to manage Diplodia tip blight. Tebuconazol is not labeled for management of pine diseases and although debacarb is labeled for use in managing other tip blight and canker diseases of trees, it is not labeled for Diplodia tip blight of pines.

Fungicide injections neither "cured" pines of Diplodia tip blight disease nor did it prevent symptomless trees from developing tip blight. In the latter case, it is possible that latent infections were already prevalent and that the fungicides were not distributed to these latent infection sites because of blocking by necrophylactic periderm (Flowers et al. 2006). Under stress such as drought, latent infections may be able to convert to pathogenic ones. Injection with debacarb appeared to slow the progress of tip blight in already diseased trees, but this trend was not statistically significant as a result of highly variable disease levels between trees and as a result of loss of some trees to tip blight before the experiment was completed. In the younger, less diseased pines, disease progress was not affected by debacarb. In both experiments, fungicide injections did not reduce the presence of latent infections. Latent infections in the younger Expt. 2 trees increased over time probably because the pathogen becomes more available on infected cones over time.

During the injection process, some of the capsules quickly filled with pitch from the tree. Thus, it is difficult to know whether all capsules were actually emptied into the injection sites. Our results are not encouraging for arborists who would like to use fungicide injections for Diplodia tip blight management in Austrian pines. Other research trials on injection of systemic fungicides for tip blight management have been inconclusive (Tisserat 2004).

\section{Basal Drench for Tip Blight Management}

Tip blight percentages suggest that Diplodia tip blight development was slowing down in paclobutrazol-treated pines at the end

Table 4. Effect of paclobutrazol on Austrian pine tree growth in 2005.

\begin{tabular}{llll}
\hline & $\begin{array}{l}\text { 1-year trunk } \\
\text { diameter increase } \\
\text { in cm (in) }\end{array}$ & $\begin{array}{l}\text { 1-year shoot } \\
\text { terminal growth } \\
\text { in cm (in) }\end{array}$ & $\begin{array}{l}\text { 1-year lateral } \\
\text { branch growth } \\
\text { in cm (in) }\end{array}$ \\
\hline Paclobutrazol & $0.7(0.3) \mathrm{a}$ & $12.5(5.0) \mathrm{a}$ & $10.3(4.1) \mathrm{a}$ \\
Water & $1.0(0.4) \mathrm{a}$ & $15.8(6.3) \mathrm{b}$ & $11.3(4.5) \mathrm{a}$ \\
\hline
\end{tabular}

${ }^{2}$ In a column, means bearing the same letter are not significantly different (Waller-Duncan K-ratio test, $P=0.05$ ). 
of our experiment, but these differences were not statistically different. Similarly, latent infections in these trees did not appear to decrease in frequency as quickly as in water-treated trees. However, these trends may indicate that latent infections are converting to active infections more slowly in the paclobutrazol-treated trees. The current study did not provide definitive evidence that paclobutrazol root flare basal treatments will cure pines of tip blight disease or stop disease progress.

\section{Implications for Arboriculture}

Arborists recommending landscape trees will want to be aware that, in some instances, Austrian pines may not be the best choice of tree to plant because of their extreme susceptibility to tip blight disease. Their useful lifetime in the landscape will be less than 25 years in most cases, and after the age of approximately 13 years, they are likely to become disfigured from the disease. Management of Diplodia tip blight in already established pines is difficult. Foliar fungicide sprays are difficult to apply to large trees, especially when there are numerous trees to treat, and they are often ineffective. Based on research reported here, current alternative fungicide treatments are not likely to be any more effective. Replication in tree disease management trials is a necessary step for product testing because what may be effective on one or two individual trees may not work on other trees nearby. Arborists should also appreciate the difficulties of conducting replicated experiments on mature trees because not all trees are uniformly infected at the start of the experiment and each tree is growing in a unique habitat. This can lead to more variable results and difficult statistical analysis.

Acknowledgments. We thank UK Plant Pathology Department technicians Ed Dixon and Etta Nuckles; and summer student interns Myriam Besson, Hugues Chopy, Claudia Cotton, Christelle Drévillon, Natalie Godbert, Valérie Jean, Stephanie Jeandot, Stéfane Kihl, Jean-Bernard Magnin, Fanny Moine, Céline Moser, Florence Nomade, Emmanuelle Paganelli, Sabine Pauly, Bruno Poupard, Maria Schira, and Gilles Vache. We appreciate research support from the Mauget Company, Rainbow Tree Care Scientific Advancements, and the Kentucky NurseryLandscape Fund.

\section{LITERATURE CITED}

Anonymous. 2002. Cambistat ${ }^{\mathrm{TM}}$ Improving the Health of Your Trees. Brochure. Rainbow Treecare Scientific Advancements, Minneapolis, MN.

Bachi, P.R., and J.L. Peterson. 1985. Enhancement of Sphaeropsis sapinea stem invasion of pines by water deficits. Plant Disease 69:798-799.

Blaedow, R.A., W.R. Chaney, P.C. Pecknold, and H.A. Holt. 2006. Investigation of fungicidal properties of the tree growth regulator pacloutrazol to control apple scab. Arboriculture and Urban Forestry 32:67-73.

Dirr, M.A. 1998. Manual of Woody Landscape Plants. Stipes Publishing, Champaign, IL. 1187 pp.

Elliott, M., and R. Edmonds. 2008. Injected treatments for management of madrone canker. Arboriculture and Urban Forestry 34: $110-115$.

Flowers, J., J. Hartman, and L. Vaillancourt. 2003. Detection of latent Sphaeropsis sapinea infections in Austrian pine tissues using nested-polymerase chain reaction. Phytopathology 93: 1471-1477.
2006. Histology of Diplodia pinea in diseased and latently infected Pinus nigra shoots. Forest Pathology 36:447-459.

Flowers, J.L., E. Nuckles, J.R. Hartman, and L.J. Vaillancourt. 2001. Latent infection of Austrian and Scots pine tissue by Sphaeropsis sapinea. Plant Disease 85:1107-1112.

Gilman, E.F., and D.G. Watson. 2006. Pinus nigra: Austrian Pine. Publication ENH-627. Environmental Horticulture Department, Florida Cooperative Extension Service, IFAS, University of Florida.

Hartman, J., G. Mussey, and W. Fountain. 1995. Evaluation of Landscape Austrian Pines for Pine Tip Blight Disease. Kentucky Agricultural Experiment Station Nursery Landscape Program 1994 Research Report. SR-94-1:31.

Helton, A.W., and W.J. French. 1962. Toxicity and translocation characteristics of six fungicidal compounds in plum and prune trees. Phytopathology 52:1050-1056.

Helton, A.W., and A.E. Harvey. 1963. Absorption, toxicity and bioassay of high-potency fungicides in Prunus domesticus. Phytopathology 53:895-898.

Jacobs, K.A., and L.C. Berg. 2000. Inhibition of fungal pathogens of woody plants by the plant growth regulator paclobutrazol. Pest Management Science 56:407-412.

Minckler, L.S. 1955. Observations on open-grown, non-native conifers in southern Illinois. American Midland Naturalist 54:460-465.

Peterson, G. 1977. Infection, epidemiology, and control of Diplodia blight of Austrian, Ponderosa, and Scots pines. Phytopathology 67:511-514.

Sinclair, W.A., and H.H. Lyon. 2005. Diseases and Trees and Shrubs. Cornell University Press, Ithaca, NY, and London, UK. 660 pp.

Stipes, R.J. 1988. Glitches and gaps in the science and technology of tree injection. Journal of Arboriculture 14:165-172.

Tisserat, N. 1993. Sphaeropsis Tip Blight, Dothistroma Needle Blight, and Brown Spot of Pines. Extension Publication L-722. Kansas State University Agricultural Experiment Station and Cooperative Extension Service. 5 pp.

2004. Sphaeropsis Tip Blight Control. Plant Disease Alert, 15 April 2004. Extension Plant Pathology, Department of Plant Pathology, Kansas State University.

Waterman, A.M. 1943. Diplodia pinea, the cause of a disease of hard pines. Phytopathology 33:1018-1031.

John R. Hartman (corresponding author)

Extension Professor Emeritus

Department of Plant Pathology

University of Kentucky

Lexington, KY 40546-0312, U.S.

jhartman@uky.edu

Lisa J. Vaillancourt

Associate Professor

Department of Plant Pathology

University of Kentucky

Lexington, KY 40546-0312, U.S.

Jennifer L. Flowers

Assistant Professor

Spalding University

Louisville, KY 40203, U.S.

Amy M. Bateman

USDA-ARS Small Grains and Potato Research Unit

Aberdeen, ID 83210, U.S.

Résumé. Un suivi à long terme de 449 pins noirs d'Autriche poussant sur le campus de l'Université du Kentucky a révélé que la brûlure des pousses par le Diplodia a tué $84 \%$ des arbres sur 
une période de 15 ans et que les pins ont développé des niveaux accrus de maladie avec l'âge. Des traitements fongiques avec l'oxycarboxin, le debacarb, le tebucanozole ou l'eau ont été appliqués par injection dans la section inférieure du tronc ou à la souche parmi les sujets d'un bloc d'arbres matures atteints par la maladie durant quatre ans. Les traitements avec les fongicides n'ont pas permis d'influencer significativement le niveau de maladie. Le champignon causal pouvait être isolé rapidement des pousses déjà malades ou encore de celles sans symptômes en dépit du traitement. Diplodia pinea était très sensible au tebuconazole et au debacarb lors de test in vitro. L'injection à la souche de paclobutrazol a affecté la croissance des pousses mais n'a pas permis de diminuer significativement le niveau de brûlure des pousses ou de mortalité de l'arbre. Sous les conditions climatiques du Centre-Sud des États-Unis, la brûlure des pousses par le Diplodia chez le pin noir d'Autriche s'avère destructrice et très difficile à gérer.

Zusammenfassung. In einer Langzeitstudie an 449 Kiefern auf dem Campus der Universität von Kentucky wurde enthüllt, dass Diplodia-Triebsterben 84\% der Bäume in einer Periode von 15 Jahren tötete und dass die Kiefern über die Jahre zunehmende Symptome dieser Krankheit entwickelten. Die Behandlungen mit den Fungiziden Oxycarboxin, Debacarb oder Tebuconazol sowie eine Kontrolle mit Wasser wurden in den unteren Stamm und die Wurzeln von einer Gruppe älterer, erkrankter Kiefern über einen Zeitraum von 4 Jahren injiziert. Die Fungizidbehandlungen hatten keinen signifikanten Einfluß auf die erkrankten Bäume.
Der verursachende Pilz konnte sowohl aus erkrankten wie auch aus symptomlosen Trieben unabhängig von der Behandlungsart isoliert werden. Bei in vitro Versuchen zeigte sich der Pilz sehr sensitiv gegenüber Tebuconazol und Debacarb. Basale Tränkungen mit Paclobutrazol beeinflussten das Triebwachstum, aber konnten die Krankheit in ihrem Verlauf und das Absterben nicht signifikant reduzieren. Unter den klimatischen Bedingungen der mittleren, südlichen Vereinigten Staaten ist das Kiefern-Triebsterben sehr destruktiv und schwierig zu behandeln.

Resumen. Un estudio a largo plazo de 449 pinos australianos creciendo en el campus de la Universidad de Kentuchy reveló que la enfermedad del Diplodia mató 84\% de los árboles durante un período de 15 años y que los pinos desarrollaron altos niveles de la enfermedad a medida que maduraban. Los tratamientos consistentes de fungicidas oxycarboxin, debacarb, tebuconazole o agua fueron inyectados por 4 años en la parte inferior de los troncos y en la corona de las raíces de árboles individuales en un bloque de pinos enfermos. Los tratamientos fungicidas no afectaron significativamente los niveles de la enfermedad. El hongo causal pudo ser aislado fácilmente de brotes enfermos sin importar el tratamiento. Diplodia pinea fue muy sensible a tebuconazole y debacarb en pruebas del fungicida in vitro. Zanjas basales con paclobutrazol afectaron el crecimiento de los brotes pero no redujeron significativamente los niveles de la enfermedad o la mortalidad del árbol. Bajo las condiciones del clima del medio sur de los Estados Unidos, el Diplodia del marchitamiento de los brotes de los pinos australianos es destructivo y muy difícil de manejar. 